Article

\title{
Does Perceived Advertising Value Alleviate Advertising Avoidance in Mobile Social Media? Exploring Its Moderated Mediation Effects
}

\author{
Xiaolong Wei ${ }^{1}{ }^{(\mathbb{C}}$, Ilsang $\mathrm{Ko}^{2, *}$ and Alison Pearce ${ }^{3}{ }^{(\mathbb{C}}$ \\ 1 School of Management, Guangdong Ocean University, Zhanjiang 524088, China; fenglangzi0925@126.com \\ 2 College of Business Administration, Chonnam National University, Gwangju 61186, Korea \\ 3 Newcastle Business School, Northumbria University, Newcastle upon Tyne NE7 7YT, UK; \\ alison.pearce@northumbria.ac.uk \\ * Correspondence: isko@chonnam.ac.kr
}

Citation: Wei, X.; Ko, I.; Pearce, A. Does Perceived Advertising Value Alleviate Advertising Avoidance in Mobile Social Media? Exploring Its Moderated Mediation Effects. Sustainability 2022, 14, 253. https:/ / doi.org/10.3390/su14010253

Academic Editors: Hong-Youl Ha and Arminda Paço

Received: 15 October 2021

Accepted: 20 December 2021

Published: 27 December 2021

Publisher's Note: MDPI stays neutral with regard to jurisdictional claims in published maps and institutional affiliations.

Copyright: (c) 2021 by the authors Licensee MDPI, Basel, Switzerland. This article is an open access article distributed under the terms and conditions of the Creative Commons Attribution (CC BY) license (https:/ / creativecommons.org/licenses/by/ $4.0 /)$.

\begin{abstract}
It is known that perceived intrusiveness and privacy concerns, mediated by irritation, indirectly affect advertising avoidance. This research attempts to verify the importance of perceived advertising value by investigating its moderated mediation effect on the links between those endogenous variables. The research model was empirically verified with data derived from 374 valid off-line responses. Analysis found that both perceived intrusiveness and privacy concerns increased irritation in using mobile social media. Irritation caused by perceived intrusiveness and privacy concerns had positive mediating effects on advertising avoidance. Ubiquity increased perceived intrusiveness and privacy concerns, whereas personalization reduced perceived intrusiveness. Customization increased perceived intrusiveness, whereas informativeness significantly reduced it. Social interaction increased privacy concerns, whereas social integration decreased them. The moderated mediation effect of perceived advertising value among women was negative. In the low-exposure group, a negative moderated mediation effect of perceived advertising value on the relationship between irritation and advertising avoidance was also found.
\end{abstract}

Keywords: perceived advertising value; advertising avoidance; perceived intrusiveness; privacy concerns; irritation; mobile social media

\section{Introduction}

In the recent "untact" society that has emerged because of COVID-19 lockdowns and restrictions, consumers enjoy many types of user-created content in closed spaces. While consuming this content, they are easily exposed to unwanted advertising. If they perceive this unwanted advertising to have even a little value, then they may accept it and even enjoy it. To overcome customers' advertising avoidance, companies are using creative storytelling and metaphors to improve the content and quality of advertisements to make them acceptable to their customers. Since COVID-19 lockdowns and restrictions have increased the breadth and depth of online interactions, both person-to-person and company-to-customer, most companies and advertising agencies have concentrated heavily on using interstitials between these interactions and have used commercial methods and incentives that eventually lead to purchases. Substantial research has been conducted to enhance advertising acceptance, effectiveness, and forwarding [1-20].

Unlike advertising in traditional mass media (e.g., magazines, TV, radio, and news) and general internet advertising, there have been few studies examining advertising avoidance in a mobile social media. Along with the advantages of mobile social media, mobility and socialization increase the opportunities to access advertising information and facilitate a viral e-WOM effect [21]. The challenges of perceived advertising intrusiveness on the Internet $[1,20]$ and privacy concerns in social networking related to advertising $[12,22,23]$ cannot be treated less seriously in mobile social media. 
According to information processing theory, users prefer executive functioning and acquire information using a top-down method when accessing the Internet [24]. If advertising impedes the main goal, such as by popping up at irregular intervals in mobile social media, it will be an interruption, which can easily lead to negative attitudes such as irritation, ultimately resulting in advertising avoidance [7]. Privacy concerns are another recent issue related to behavioral targeting or tailored advertising in social networking $[12,25,26]$. Privacy concerns have been examined as a determinant of attitudes toward advertising, advertising acceptance, and advertising effectiveness in both traditional and Internet-based advertising [1,15,16,22,27-29]. Investigating the roles of perceived intrusiveness and privacy concerns and their influence on advertising avoidance in mobile social media has emerged as an important topic in advertising research.

Advertising value is a measure of advertising effectiveness. In prior studies, advertising value was perceived as a predictor of attitudes toward advertising [12,14,30]. Edwards et al. [31] stated that when advertisements provide value, they become less interruptive and less irritating. Certain demographic characteristics, such as gender [15,16,32-34], frequency of exposure to advertising [35-37], and media usage time [1], affect the receptivity to, effectiveness of, and attitudes toward advertising. Demographic characteristics have been used to assess the moderating effects of perceived advertising value on perceived intrusiveness and irritation, which influence advertising avoidance [38]. Elucidating how perceived advertising value affects advertising avoidance in terms of demographic characteristics would provide important information to help mitigate advertising avoidance.

Recent advances in collaboration technology have greatly increased the quality of advertisements by applying ubiquity, personalization, customization, information richness, entertainment elements, social interaction, and social integration. Many studies have shown that these motivational factors are highly related to advertising effectiveness. In this study, we attempt to prove the direct effect of these motivating factors on perceived intrusiveness and privacy concerns as well as their indirect effects on irritation and advertising avoidance. We also try to verify the importance of perceived advertising value by investigating its moderated mediation effect on the links between those endogenous variables. Our key questions are as follows:

1. Do ubiquity, personalization, customization, information richness, entertainment, social interaction, and social integration affect perceived intrusiveness and privacy concerns?

2. How do perceived intrusiveness and privacy concerns mediated by irritation influence advertising avoidance in mobile social media?

3. Considering the effects of demographic characteristics, does perceived advertising value effectively alleviate advertising avoidance in mobile social media?

\section{Literature Review}

\subsection{Advertising Avoidance in Mobile Social Media}

Advertising avoidance refers to "all actions by media users that differently reduce their exposure to ad contents" [39]. Studies of advertising avoidance have focused on the context of traditional mass media, the Internet [10,31,40], mobile platforms [27,29], or SNS [22,41]. However, little research has focused on advertising avoidance in mobile social networks [42]. Research into advertising avoidance on the Internet indicates that avoidance involves a combination at the cognitive, mechanical, and behavioral levels [31]. In a keyword analysis of advertising, it is desirable to combine behavioral and mechanical avoidance into physical avoidance [10]. We believe that these three types of advertising avoidance are applicable to mobile social media as well: mechanical avoidance entails using "settings" to avoid receiving future messages, behavioral avoidance refers to deleting advertisements intentionally, and cognitive avoidance refers to paying no attention to ads or ignoring them.

One study of social network advertising (SNA) argued that advertising in social media can be conceptualized as existing in either explicit forms (e.g., banner ads or videos) that are merely adaptations of traditional media to the Internet or implicit forms (e.g., fan pages 
or firm-related "tweets") that are generated via interactions between consumers and advertisers [15]. Recently, there have been several studies focusing on specific advertising genres in social networks, such as posted information for eWOM advertising [43], brand loyalty in brand microblogs [44,45], and tailored versus invasive personalized advertising [22]. In this study, we focused on general types of advertising, such as brand applications [19], banner ads [7], message or text ads [17,18,46], or video ads [47], and we assumed that "interactivity" via advertising or mobile social media affects advertising avoidance.

Advertising in mobile social media can leverage the advantages of "mobile" [48] and "social" $[49,50]$, but it also has limitations. One typical challenge associated with social media is the improper collection of personal information and search histories, which may lead to privacy concerns $[12,22,23]$. Further, unlike traditional advertising media, accessing mobile social media is highly goal-directed [24], wherein inconvenient advertising campaigns that users perceive as impediments may lead to negative attitudes, which most frequently lead to ad avoidance by Internet consumers [7]. We assume that in mobile social media, there is frequent and serious advertising avoidance. Among the primary determinants of advertising avoidance, we have investigated the topics that were examined in previous research, such as irritation $[11,14,31,51,52]$, perceived intrusiveness $[1,20,38]$, privacy concerns $[8,15,16,28,37,53]$, "ad clutter" [54], and prior negative experience [27,53]. We selected perceived intrusiveness and privacy concerns as antecedents for advertising avoidance.

\subsection{Advertising in Mobile Social Media}

The psychological needs underlying the use of specific media as well as user motivation drive specific behavior that aims for gratification to fulfill intrinsic needs. Various types of gratification involved in the use of specific media have been examined, including traditional media [30], the Internet $[1,6,15,55]$, mobile $[5,11,14]$, and mobile social media $[2,24]$. A useful framework can explain audience motivations to adopt and use media, but the experiences and gratifications obtained from media also affect the response to an ad [30].

Researchers [24,56] have highlighted ubiquity as a unique feature of mobile devices, which provide service and access to information anytime and anywhere. Mobility is an opportunity for advertising [24,48]. Personalization and customization represent two distinct types of information tailoring in information system communication. Personalization emphasizes system-initiated tailoring, whereby the system automatically tracks personal information and delivers ad content that matches user preferences. Customization is userinitiated tailoring, which allows users to inform the system of their interests by means of "personal settings" [52,57]. These two types of information tailoring were compared in a study of location-based advertising (LBA) [6]. In our study, we propose that ubiquity and information tailoring are convenient features for users who are accessing advertising in mobile social media.

Informativeness and entertainment are the two primary legitimate functions of advertising. Informativeness helps users make decisions, whereas entertainment is the ability to gratify basic needs, such as diversion, emotional release, and escapism [11,58]. Informativeness and entertainment have been used as the fundamental elements in investigating advertising value, which subsequently affects attitudes or behavior toward advertising [1,2,4,6,12,15,24,55].

Social interaction refers to people actively participating in customer discussions on a website or providing their own opinions on the sites [6]. In mobile social network services (SNS) (e.g., Facebook and Kakao Talk), "integrative gratifications" have been identified as strengthening individual trust, confidence, and connections with acquaintances. However, 'social interactive' gratifications have been identified as being derived from strong interpersonal communication exchange [24]. Consistent with how the two aspects of social networking use motivations based on the need for online social capital and psychological well-being [55], we define social gratifications in terms of social interaction and social integration. 


\section{Theoretical Background and Hypotheses}

\subsection{Irritation and Advertising Avoidance}

The theory of reasoned action (TRA), which "aims to explain the relationship between attitudes and behaviors within human actions," asserts that individual actions or behavioral intention are initiated directly by attitude [59]. In Ducoffe's web advertising model, irritation is the antecedent significantly associated with advertising value, which in turn influences attitudes toward advertising [38]. This study defines irritation as "the extent to which the advertising is messy and irritating to others." Attitude toward an advertising campaign should capture its overall favorable or unfavorable evaluation [20]. People develop either positive or negative attitudes toward advertising [51,60]. In our study, we focus on the predictors that determine advertising avoidance. We select irritation as a negative attitude and propose that it directly affects advertising avoidance in mobile social media. Based on the above discussion, we propose the following hypothesis.

\section{Hypothesis 1 (H1). Irritation increases advertising avoidance in mobile social media.}

\subsection{Perceived Intrusiveness, Privacy Concerns, and Irritation}

Psychological reactance theory state that "reactance is a motivational reaction to offers, rules, or regulations that threaten or eliminate specific behavioral freedoms" and "reactance occurs when a person feels that someone or something is taking away his or her choices or limiting the range of alternatives [61]." The perceived intrusiveness of advertising is a cognitive evaluation of the degree to which the advertisement interrupts individual goals [31]. Unlike traditional advertising media, mobile social media with Internet features lead to a more goal-directed situation [10]. According to executive functioning, users assume greater power to collect or tailor the exact information they are attempting to access [24]. The presence of advertising on a small mobile screen may impede the execution of main tasks, such as seeking information, entertainment, or social interaction, which may threaten both personal control and freedom. According to psychological reactance theory, this impediment and threat comes from advertising intrusiveness, which results in negative outcomes. Perceived intrusiveness accounts for many of the differences in the overall attitude toward mobile advertising campaigns [20]. Studies have confirmed that perceived intrusiveness is associated with negative emotions [31,62]. However, there have been few empirical studies investigating the relationship between perceived intrusiveness and irritation. We propose that in mobile social media, perceived intrusiveness results in a negative attitude of "irritation" toward advertising, which in turn induces advertising avoidance, as stated in the following hypothesis.

Hypothesis 2 (H2). Perceived intrusiveness increases irritation in using mobile social media.

\subsection{Privacy Concerns}

Privacy concerns are defined as "SNS users' apprehension about the loss or abuse of their private information" $[1,28,43,53]$. In a study of Internet information privacy, specifically based on "concern for information privacy" (CFIP), the dimensions of "Internet-user information privacy concern" (IUIPC) were developed as "collection, awareness, and control." Collection refers to the degree to which a person is concerned about the volume of individual-specific data processed by others in terms of the benefits received, awareness relates to information transparency and the disclosure of specific information, and control indicates the freedom to either accept or reject the process or decision outcome [53]. A perception of an invasion of privacy by advertisements in mobile social media, which may result from the loss of benefits received from advertising, information transparency and the disclosure of specific information, and the control of personal information, leads to specific apprehensions. In other words, the invasiveness or intrusiveness of advertising may cause privacy concerns by users of mobile social media. Privacy concerns in the form of consumers' apprehension about their information loss and abuse may lead to negative 
outcomes. Prior studies focused on advertising have empirically confirmed that privacy concerns are significantly associated with attitudes towards advertising [1,15,16,41]. We propose that privacy concerns induced by advertising significantly increase irritation, a negative attitude toward advertising. Hence, we propose the following hypotheses:

Hypothesis 3 (H3). Perceived intrusiveness increases privacy concerns by users of mobile social media.

Hypothesis 4 (H4). Privacy concerns increase irritation in users of mobile social media.

\subsection{Perceived Advertising Value}

Advertising value is defined as "a subjective evaluation of the relative worth or utility of advertising to consumers" and a predictor of intentions and attitudes toward advertising [38]. In a study examining Internet advertising in the form of pop-up ads, "When ads provide value, either in the form of information or entertainment, they are perceived as less of an interruption, are less irritating [63]." Investigations into other types of advertising (e.g., social network advertising, in-game advertising, agent-based recommendation advertising, and keyword advertising) have shown that gender plays an important role in shaping advertising receptivity [15,16,33,34]. Advertising repetition significantly increases its effectiveness, as was empirically proven in a series of experimental designs [1,35-37] which suggested that consumer attitudes toward advertising develop depending on the time spent with social media or the frequency of social media visits. In our study, we investigate the moderating effects of perceived advertising value on the paths ranging from perceived intrusiveness to advertising avoidance as mediated by irritation, while considering the role of gender, perceived advertising exposure frequency, and the amount of time spent on mobile social media. We propose the following related hypotheses.

Hypothesis 5 (H5). Perceived advertising value moderates the effects ranging from irritation to advertising avoidance.

Hypothesis 5a (H5a). The moderating effects of perceived advertising value differ between gender groups.

Hypothesis $\mathbf{5 b} \mathbf{b} \mathbf{H} \mathbf{5 b})$. The moderating effects of perceived advertising value differ between highand low-exposure groups.

Hypothesis $\mathbf{5 c}(\mathbf{H 5 c})$. The moderating effects of perceived advertising value differ between groups with high and low user times.

\subsection{Ubiquity, Personalization, and Customization}

Compared to personal computers, ubiquity is the most important and distinctive asset of mobile devices [56]. The role of ubiquity in advertising was shown to be negative in some studies investigating mobile advertising, which was attributed to consumers being increasingly conscious of their privacy concerns, fearing the possibility of information leakage, or having a lack of control over unexpected intrusions [64]. Therefore, the role of ubiquity for advertising is negative for mobile social media, despite the convenience of mobile devices. Hence, we propose the following hypotheses.

Hypothesis 6a (H6a). Ubiquity increases the perceived intrusiveness of mobile social media.

Hypothesis $\mathbf{6 b}$ (H6b). Ubiquity increases privacy concerns about mobile social media.

For mobile SNS, consumers are active, goal-directed users who are conscious of their own motivations. Customization emphasizes user controllability in tailoring and information delivery [65]. Because a user's cognitive load is limited and because mobile 
devices have small screens on which to show advertisements, "personal settings" based on advertising may reduce the freedom of users to enjoy mobile social media, particularly when the main task of focus is not advertising. However, ensuring user control of personal information and the system largely guarantees user privacy.

Unlike customization, personalization emphasizes automatic relevance, wherein the system tracks personal information and delivers ad content that matches the users' preferences [66]. During the delivery of matched ad content based on personal preferences, both individual demographics and geographic information, which are highly related, attenuate the perceived intrusiveness. However, the automated system tracking may lead to a loss of control, the abuse of a user's information, and the compromising of personal information, all of which aggravate privacy concerns [67]. Given the above discussion, we propose the following hypotheses.

Hypothesis 7a (H7a). Personalization decreases perceived intrusiveness in mobile social media.

Hypothesis $\mathbf{7 b} \mathbf{( H 7 b ) . ~ P e r s o n a l i z a t i o n ~ i n c r e a s e s ~ p r i v a c y ~ c o n c e r n s ~ i n ~ m o b i l e ~ s o c i a l ~ m e d i a . ~}$

Hypothesis $7 \mathbf{c}(\mathbf{H 7 c )}$. Customization increases perceived intrusiveness in mobile social media.

Hypothesis $\mathbf{7 d} \mathbf{( H 7 d ) . ~ C u s t o m i z a t i o n ~ d e c r e a s e s ~ p r i v a c y ~ c o n c e r n s ~ i n ~ m o b i l e ~ s o c i a l ~ m e d i a . ~}$

\subsection{Informativeness and Entertainment}

Informativeness and entertainment are the two primary legitimate functions of advertising $[1,2,4,6,11,12,15,55,58,68]$. Some studies have confirmed that attitude toward advertising is developed by informativeness and entertainment $[15,17,18]$. We define informativeness and entertainment as relievers of perceived intrusiveness and privacy concerns, and we propose that they reduce perceived intrusiveness and privacy concerns as follows:

Hypothesis 8a (H8a). Informativeness decreases perceived intrusiveness in mobile social media.

Hypothesis $\mathbf{8 b} \mathbf{( H 8 b ) . ~ I n f o r m a t i v e n e s s ~ d e c r e a s e s ~ p r i v a c y ~ c o n c e r n s ~ i n ~ m o b i l e ~ s o c i a l ~ m e d i a . ~}$

Hypothesis 8c (H8c). Entertainment reduces perceived intrusiveness in mobile social media.

Hypothesis 8d (H8d). Entertainment reduces privacy concerns in mobile social media.

\subsection{Social Interaction and Social Integration}

Studies investigating Internet advertising have shown that social interaction is positively associated with human-human interaction but is negatively associated with humanmessage interaction $[6,69]$. Prior studies have treated peer influence and self-brand congruity in the context of SNA and in-game advertising [15,16]; we refine them into social interaction and social integration in mobile social media [24]. The findings of prior studies have suggested that social interaction and social integration show mostly positive effects in the context of advertising [1,4,6,15].

In our study, we assume that social interaction and social integration are benefits derived from social capital and well-being $[45,70]$. Social capital is the benefit derived from social network relationships, whereas social well-being refers to global cognitive judgments of self [55]. Motivations using media gratify consumer needs [71]. Following the previous studies, we propose that social interaction and social integration play positive roles in advertising, and we develop the following hypotheses.

Hypothesis 9a (H9a). Social interaction reduces perceived intrusiveness in mobile social media.

Hypothesis $9 \mathbf{b}(\mathbf{H 9 b})$. Social interaction reduces privacy concerns in mobile social media. 
Hypothesis 9c (H9c). Social integration reduces perceived intrusiveness in mobile social media.

Hypothesis 9d (H9d). Social integration reduces privacy concerns in mobile social media.

\section{Methodology and Research Design}

\subsection{Data Collection}

To test the research model and hypotheses, we conducted off-line surveys and collected 434 responses. Of those, we used 374 valid responses for statistical analysis. The demographic statistics show that $52.1 \%$ of the participants were male $(n=195)$ and $47.9 \%$ were female $(n=179)$. In age, $93.3 \%$ were in their twenties, and $6.7 \%$ were of other ages. In educational background, $86.4 \%$ of the participants were undergraduate students. Among the participants, $85.8 \%$ reported using mobile social applications over one hour daily, which is relatively high. The main mobile social media applications that we investigated were KaKao Talk ( $n=308$ users) and Facebook ( $n=112$ users). The types of advertising that appeared most often in mobile social media were messages or text ads $(n=133,35.6 \%)$, banner ads $(n=125,33.4 \%)$, brand app ads $(n=97,25.9 \%)$, and video ads $(n=62,16.6 \%)$. The degree of perceived advertising exposure was high: $75.9 \%$ of the participants reported that they unintentionally received ads in mobile social media more than three times a day. In Table 1, we summarize the participants' demographic statistics. Approximately $80 \%$ of the participants were college students, who were the most active social network users [1,72].

Table 1. Results of demographic analysis.

\begin{tabular}{|c|c|c|c|}
\hline Demographics & Percentage (\%) & Demographics & Percentage $(\%)$ \\
\hline Gender & & Mobile Social Application * & \\
\hline Male & 52.10 & KaKao Talk & 82.40 \\
\hline \multirow[t]{2}{*}{ Female } & 47.90 & Facebook & 29.90 \\
\hline & & WeChat & 6.40 \\
\hline Age & & Twitter & 1.30 \\
\hline $20 \mathrm{~s}$ & 93.30 & Line & 2.10 \\
\hline $30 \mathrm{~s}$ & 4.30 & Others & 6.70 \\
\hline $40 \mathrm{~s}$ & 1.30 & & \\
\hline \multirow[t]{2}{*}{ Over 50 s } & 1.10 & Advertisement Types * & \\
\hline & & Message or Text Ads & 35.60 \\
\hline $\begin{array}{l}\text { Educational } \\
\text { Background }\end{array}$ & & Banner Ads & 33.40 \\
\hline $\begin{array}{l}\text { High School } \\
\text { Graduate }\end{array}$ & 11.30 & Brand App Ads & 25.90 \\
\hline $\begin{array}{c}\text { College } \\
\text { Undergraduate }\end{array}$ & 81.20 & Video Ads & 16.60 \\
\hline Master & 1.90 & Others & 1.60 \\
\hline Doctor & 3.20 & & \\
\hline \multirow[t]{2}{*}{ Others } & 2.40 & $\begin{array}{l}\text { Perceived Advertising } \\
\text { Exposure Frequency }\end{array}$ & \\
\hline & & One Time & 4.00 \\
\hline $\begin{array}{l}\text { Mobile Social } \\
\text { Media Use Time }\end{array}$ & & 2-3 Times & 16.00 \\
\hline Within One Hour & 14.20 & 4-5 Times & 23.80 \\
\hline Over 1 -Within $3 \mathrm{~h}$ & 55.40 & Over 6 Times & 56.10 \\
\hline Over 3-Within $5 \mathrm{~h}$ & 21.00 & & \\
\hline \multirow[t]{3}{*}{ Over $5 \mathrm{~h}$} & 9.90 & Sharing Experience & \\
\hline & & Yes & 47.00 \\
\hline & & No & 53.00 \\
\hline
\end{tabular}

* Survey questions with multiple choices. 


\subsection{Measures}

Ubiquity was developed as a second-order reflective construct consisting of time saving (3 items), spatial flexibility ( 3 items), and contextual flexibility (5 items), which were adapted from prior studies $[2,7,24,27,56]$ and adjusted to fit mobile social media. Personalization and customization were adapted from a study on customization in location-based advertising [6]. Measures of informativeness and entertainment were adapted from prior advertising research $[1,14-16,30,73]$. Social interaction and social integration were developed from prior studies investigating social motivation in social media [1,2,13,15,30,73-75]. Factors such as perceived intrusiveness, privacy concerns, irritation, perceived advertising value, and advertising avoidance were developed from Ducoffe's investigations of web advertising [38] and from studies on privacy concerns $[28,53,74,76]$ and advertising avoidance $[31,40,41]$. We conducted an exploratory factor analysis (EFA) to ensure the validity and reliability of the research factors. We deleted the measures with a factor loading of less than 0.5 after varimax rotation. Finally, the EFA models showed goodness of fit, where the Eigenvalues of the factors were higher than 1, and the KMO values were almost all higher than $0.9, \mathrm{KMO}$ value in EFA for endogenous factors is 0.895, indicating that the EFAs for both exogenous and endogenous factors were acceptable (results shown in Tables 2 and 3).

Table 2. Measures and results of EFA on exogenous factors.

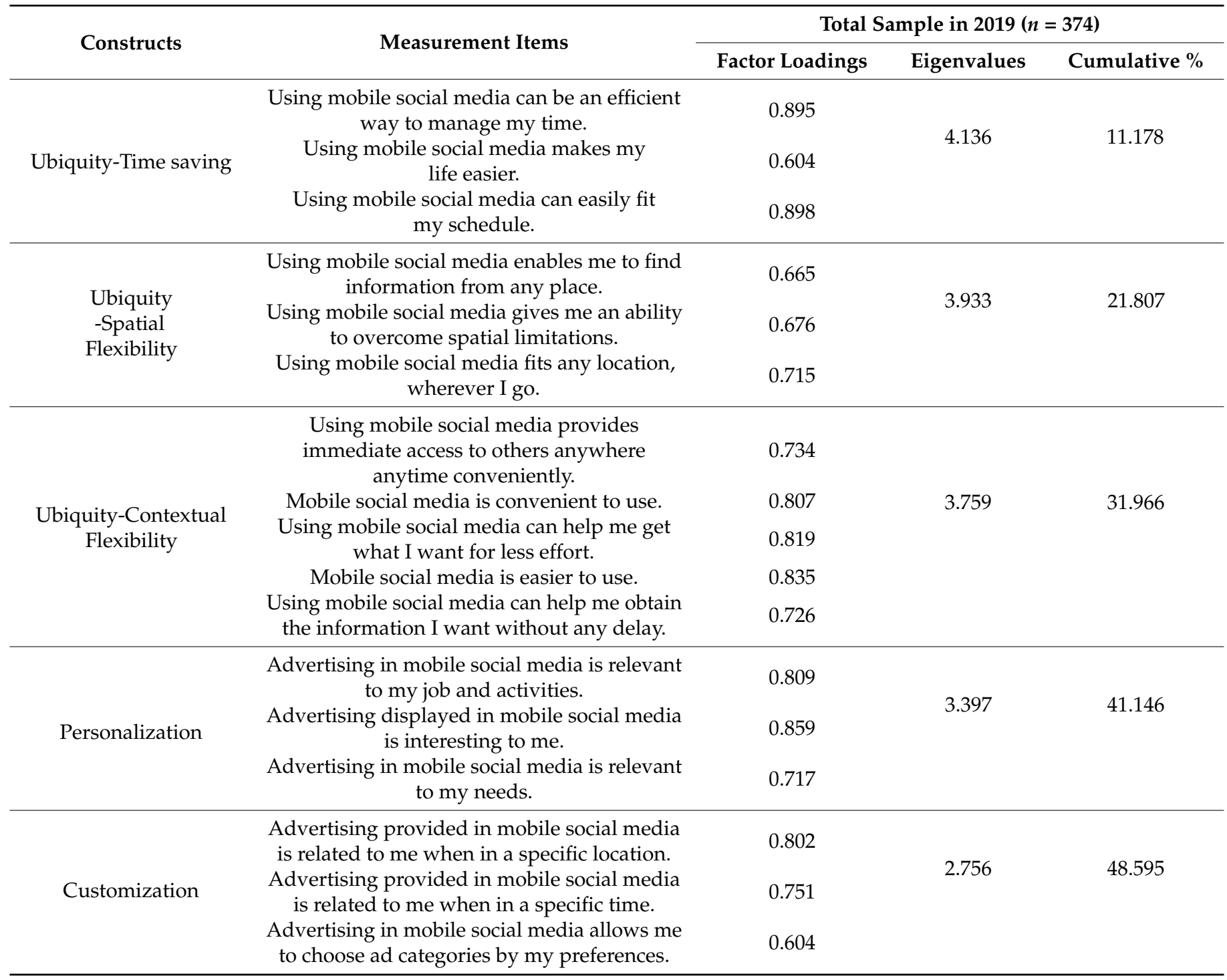


Table 2. Cont.

\begin{tabular}{|c|c|c|c|c|}
\hline \multirow{2}{*}{ Constructs } & \multirow{2}{*}{ Measurement Items } & \multicolumn{3}{|c|}{ Total Sample in $2019(n=374)$} \\
\hline & & Factor Loadings & Eigenvalues & Cumulative $\%$ \\
\hline \multirow{4}{*}{ Informativeness } & $\begin{array}{l}\text { Advertising in mobile social media is a } \\
\text { valuable information source of a } \\
\text { product/service. }\end{array}$ & 0.673 & \multirow{4}{*}{2.664} & \multirow{4}{*}{55.796} \\
\hline & $\begin{array}{l}\text { Advertising in mobile social media is a } \\
\text { convenient information source of a } \\
\text { product/service. }\end{array}$ & 0.725 & & \\
\hline & $\begin{array}{l}\text { Advertising in mobile social media makes } \\
\text { information immediately accessible. }\end{array}$ & 0.621 & & \\
\hline & $\begin{array}{l}\text { Advertising in mobile social media keeps me } \\
\text { up-to-date for free. }\end{array}$ & 0.768 & & \\
\hline \multirow{5}{*}{ Entertainment } & $\begin{array}{l}\text { Advertising in mobile social media is } \\
\text { enjoyable, amusing, and entertaining. }\end{array}$ & 0.696 & \multirow{5}{*}{2.206} & \multirow{5}{*}{61.758} \\
\hline & $\begin{array}{l}\text { Advertising in mobile social media } \\
\text { is pleasant. }\end{array}$ & 0.806 & & \\
\hline & $\begin{array}{l}\text { Seeing advertising in mobile social media } \\
\text { gives me a more enjoyable and relaxing time. }\end{array}$ & 0.820 & & \\
\hline & $\begin{array}{l}\text { Seeing advertising in mobile social media } \\
\text { derives fun and enjoyment. }\end{array}$ & 0.811 & & \\
\hline & $\begin{array}{l}\text { Seeing advertising in mobile social media } \\
\text { entertains and stimulates my mind. }\end{array}$ & 0.584 & & \\
\hline \multirow{5}{*}{$\begin{array}{c}\text { Social } \\
\text { Interaction }\end{array}$} & $\begin{array}{l}\text { I will recommend advertising in mobile social } \\
\text { media to others. }\end{array}$ & 0.762 & \multirow{5}{*}{2.199} & \multirow{5}{*}{67.702} \\
\hline & $\begin{array}{l}\text { I will say positive things about advertising in } \\
\text { mobile social media to others. }\end{array}$ & 0.745 & & \\
\hline & $\begin{array}{c}\text { I need to interact with people through mobile } \\
\text { social media or advertising in it to make } \\
\text { myself interested in things that happen } \\
\text { outside. }\end{array}$ & 0.745 & & \\
\hline & $\begin{array}{l}\text { To feel like a part of a larger community, I } \\
\text { need to interact with people through mobile } \\
\text { social media or advertising in it. }\end{array}$ & 0.710 & & \\
\hline & $\begin{array}{l}\text { I need to spend time supporting general } \\
\text { online community activity through mobile } \\
\text { social media or advertising in it. }\end{array}$ & 0.555 & & \\
\hline \multirow{6}{*}{$\begin{array}{c}\text { Social } \\
\text { Integration }\end{array}$} & $\begin{array}{l}\text { The brands advertised in mobile social } \\
\text { network advertising are consistent with how I } \\
\text { see myself. }\end{array}$ & 0.652 & \multirow{6}{*}{1.748} & \multirow{6}{*}{72.427} \\
\hline & $\begin{array}{l}\text { The brands advertised in mobile social } \\
\text { network advertising cater to people like me. }\end{array}$ & 0.675 & & \\
\hline & $\begin{array}{l}\text { The brands advertised in mobile social } \\
\text { network advertising reflect who I am. }\end{array}$ & 0.725 & & \\
\hline & $\begin{array}{l}\text { Interactions through mobile social network } \\
\text { advertising can expand my personal/social } \\
\text { networks. }\end{array}$ & 0.744 & & \\
\hline & $\begin{array}{l}\text { Interactions through mobile social network } \\
\text { advertising can help me derive gratification } \\
\text { from influencing others. }\end{array}$ & 0.653 & & \\
\hline & $\begin{array}{l}\text { Interactions through mobile social network } \\
\text { advertising can reinforce my } \\
\text { credibility/authority or status/reputation. }\end{array}$ & 0.729 & & \\
\hline
\end{tabular}

KMO value $=0.911, \chi^{2}{ }_{(666)}=9119.319, p=0.000$. 
Table 3. Measures and results of EFA on endogenous factors.

\begin{tabular}{|c|c|c|c|c|}
\hline \multirow{2}{*}{ Constructs } & \multirow{2}{*}{ Measurement Items } & \multicolumn{3}{|c|}{ Total Sample in $2019(n=374)$} \\
\hline & & Factor Loadings & Eigenvalues & Cumulative \% \\
\hline \multirow{3}{*}{ Perceived Intrusiveness } & $\begin{array}{c}\text { Advertising in mobile social media is } \\
\text { invasive. }\end{array}$ & 0.813 & \multirow{3}{*}{3.506} & \multirow{3}{*}{20.622} \\
\hline & $\begin{array}{c}\text { Advertising in mobile social media is } \\
\text { interfering. }\end{array}$ & 0.843 & & \\
\hline & Advertising in mobile social media is forceful. & 0.810 & & \\
\hline \multirow[t]{2}{*}{ Privacy Concerns } & $\begin{array}{l}\text { It usually bothers me when advertisers ask } \\
\text { for my personal information in mobile social } \\
\text { media. }\end{array}$ & 0.811 & \multirow[t]{2}{*}{2.805} & \multirow[t]{2}{*}{37.124} \\
\hline & $\begin{array}{c}\text { I am concerned about the potential misuse of } \\
\text { personal data in mobile social media. }\end{array}$ & 0.855 & & \\
\hline \multirow{3}{*}{$\begin{array}{c}\text { Perceived } \\
\text { Advertising Value }\end{array}$} & Advertising in mobile social media is useful. & 0.880 & \multirow{3}{*}{2.681} & \multirow{3}{*}{52.896} \\
\hline & $\begin{array}{c}\text { Advertising in mobile social media is } \\
\text { valuable. }\end{array}$ & 0.924 & & \\
\hline & $\begin{array}{l}\text { Advertising in mobile social media } \\
\text { is important. }\end{array}$ & 0.884 & & \\
\hline \multirow{5}{*}{ Irritation } & $\begin{array}{c}\text { Advertising in mobile social media is } \\
\text { irritating, annoying, intrusive, deceptive, and } \\
\text { confusing. }\end{array}$ & 0.649 & \multirow{5}{*}{2.399} & \multirow{5}{*}{67.008} \\
\hline & $\begin{array}{l}\text { Advertising in mobile social media disturbs } \\
\text { my use of mobile social media. }\end{array}$ & 0.696 & & \\
\hline & $\begin{array}{l}\text { Advertising in mobile social media is not } \\
\text { enjoyable, and I don't like it. }\end{array}$ & 0.773 & & \\
\hline & $\begin{array}{l}\text { I am not satisfied with the service provided } \\
\text { by advertising in mobile social media. } \\
\text { I feel uncomfortable in surfing through }\end{array}$ & 0.800 & & \\
\hline & $\begin{array}{l}\text { advertising in mobile social media, and doing } \\
\text { that is not a good way to spend my time. }\end{array}$ & 0.791 & & \\
\hline \multirow{4}{*}{ Advertising Avoidance } & $\begin{array}{l}\text { I will neglect or not pay attention to } \\
\text { advertising in mobile social media. }\end{array}$ & 0.620 & \multirow{4}{*}{1.616} & \multirow{4}{*}{76.514} \\
\hline & $\begin{array}{l}\text { I will delete the messages from my } \\
\text { smartphone if I think it is advertising. }\end{array}$ & 0.814 & & \\
\hline & $\begin{array}{l}\text { I will cancel the notice about advertising } \\
\text { messages in mobile social media. }\end{array}$ & 0.826 & & \\
\hline & $\begin{array}{l}\text { I don't see any advertising in mobile social } \\
\text { media and will pass right by them. }\end{array}$ & 0.748 & & \\
\hline
\end{tabular}

KMO value $=0.895, \chi^{2}{ }_{(136)}=3941.868, p=0.000$.

\section{Results}

\subsection{Measurement Model}

The convergent validity and discriminant validity of the research factors were provided from confirmatory factor analysis (CFA); the results are listed in Tables 4 and 5.

The CFA of exogenous factors provided an acceptable fit: $\chi^{2} / d f=2.022$, SRMR $=0.072$, RMSEA $=0.052, \mathrm{GFI}=0.850, \mathrm{NFI}=0.872, \mathrm{IFI}=0.931$, and CFI $=0.930$. Similarly, the overall goodness-of-fit indices in CFA for endogenous factors were good: $\chi^{2} / d f=2.284$, $\mathrm{SRMR}=0.063, \mathrm{RMSEA}=0.059, \mathrm{GFI}=0.928, \mathrm{NFI}=0.939, \mathrm{IFI}=0.965$, and CFI $=0.965$. All the estimates of the observed indicators are significant $(p<0.050)$ and strongly load on their latent factors, thus ensuring convergent validity. Further, the values of average variance extracted (AVEs) are greater than 0.5 , and the values of construct reliability (CR) are almost all above 0.7 , which ensures the convergent validity of the factors. To confirm the discriminant validity of factors, we compared the square roots of AVEs for each factor with their correlations. As presented in Table 6, the square roots of AVEs are higher than the correlations, thus ensuring the discriminant validity of factors. At the same time, to test the 
factors' reliability, we calculated Cronbach's $\alpha$ for each factor. As listed in Tables 5 and 6, almost all Cronbach's $\alpha$ values were higher than 0.81 , and Cronbach's $\alpha$ value for privacy concerns was 0.648 , which confirms the reliability of the factors [64,77].

Table 4. CFA on exogenous factors.

\begin{tabular}{|c|c|c|c|c|c|c|c|c|c|}
\hline Factors & Measures & Estimate & $\begin{array}{l}\text { Standardized } \\
\text { Estimate }\end{array}$ & S.E. & $\mathbf{T}$ & $\mathbf{P}$ & AVE & $\begin{array}{l}\text { Composite } \\
\text { Reliability }\end{array}$ & $\begin{array}{c}\text { Cronbach } \\
\alpha\end{array}$ \\
\hline \multirow{3}{*}{ Ubiquity } & Time saving & 0.837 & 0.474 & 0.113 & 7.389 & $* * *$ & \multirow[b]{2}{*}{0.537} & \multirow[b]{2}{*}{0.697} & \multirow[b]{2}{*}{0.537} \\
\hline & $\begin{array}{c}\text { Spatial } \\
\text { flexibility }\end{array}$ & 1.000 & 0.813 & & & & & & \\
\hline & $\begin{array}{l}\text { Context } \\
\text { flexibility }\end{array}$ & 0.851 & 0.851 & 0.098 & 8.675 & $* * *$ & & & \\
\hline \multirow{3}{*}{ Time Saving } & UBts1 & 0.822 & 0.796 & 0.051 & 15.994 & $* * *$ & \multirow{3}{*}{0.646} & \multirow{3}{*}{0.757} & \multirow{3}{*}{0.825} \\
\hline & UBts2 & 0.513 & 0.589 & 0.043 & 11.893 & $* * *$ & & & \\
\hline & UBts3 & 1.000 & 0.978 & & & & & & \\
\hline \multirow{3}{*}{$\begin{array}{c}\text { Spatial } \\
\text { Flexibility }\end{array}$} & UBsf1 & 0.952 & 0.773 & 0.065 & 14.589 & $* * *$ & \multirow{3}{*}{0.587} & \multirow{3}{*}{0.739} & \multirow{3}{*}{0.805} \\
\hline & UBsf2 & 1.000 & 0.827 & & & & & & \\
\hline & UBsf3 & 0.917 & 0.693 & 0.070 & 13.139 & $* * *$ & & & \\
\hline \multirow{6}{*}{$\begin{array}{l}\text { Context } \\
\text { Flexibility }\end{array}$} & UBcf1 & 1.022 & 0.688 & 0.074 & 13.839 & $* * *$ & \multirow{6}{*}{0.561} & \multirow{6}{*}{0.838} & \multirow{6}{*}{0.869} \\
\hline & UBcf2 & 1.000 & 0.808 & & & & & & \\
\hline & UBcf3 & 1.072 & 0.760 & 0.069 & 15.635 & $* * *$ & & & \\
\hline & $\mathrm{UBcf} 4$ & 1.043 & 0.818 & 0.061 & 17.072 & $* * *$ & & & \\
\hline & UBcf5 & 0.988 & 0.658 & 0.075 & 13.121 & $* * *$ & & & \\
\hline & TAps1 & 0.845 & 0.786 & 0.048 & 17.768 & $* * *$ & & & \\
\hline \multirow[t]{3}{*}{ Personalization } & TAps2 & 1.000 & 0.893 & & & & \multirow[t]{3}{*}{0.688} & \multirow[t]{3}{*}{0.723} & \multirow[t]{3}{*}{0.865} \\
\hline & TAps3 & 0.842 & 0.805 & 0.046 & 18.479 & $* * *$ & & & \\
\hline & TAct1 & 0.922 & 0.780 & 0.058 & 15.784 & $* * *$ & & & \\
\hline \multirow[t]{3}{*}{ Customization } & TAct2 & 1.000 & 0.865 & & & & \multirow[t]{3}{*}{0.602} & \multirow[t]{3}{*}{0.655} & \multirow[t]{3}{*}{0.81} \\
\hline & TAct3 & 0.832 & 0.670 & 0.062 & 13.499 & $* * *$ & & & \\
\hline & IMif1 & 0.914 & 0.750 & 0.057 & 16.141 & $* * *$ & & & \\
\hline & IMif3 & 1.000 & 0.855 & & & & & & \\
\hline Informativeness & IMif4 & 0.950 & 0.774 & 0.056 & 16.840 & $* * *$ & 0.597 & 0.732 & 0.852 \\
\hline & IMif5 & 0.850 & 0.705 & 0.057 & 14.874 & $* * *$ & & & \\
\hline & IMen1 & 0.825 & 0.689 & 0.050 & 16.528 & $* * *$ & & & \\
\hline & IMen2 & 0.927 & 0.871 & 0.035 & 26.374 & $* * *$ & & & \\
\hline Entertainment & IMen3 & 0.985 & 0.913 & 0.033 & 29.841 & $* * *$ & 0.686 & 0.739 & 0.909 \\
\hline & IMen4 & 1.000 & 0.928 & & & & & & \\
\hline & IMen5 & 0.857 & 0.710 & 0.049 & 17.368 & $* * *$ & & & \\
\hline & SCsi2 & 0.843 & 0.632 & 0.064 & 13.095 & $* * *$ & & & \\
\hline & SCsi3 & 0.824 & 0.672 & 0.058 & 14.214 & $* * *$ & & & \\
\hline Social & SCsi4 & 0.934 & 0.833 & 0.049 & 19.187 & $* * *$ & 0.566 & 0.847 & 0.868 \\
\hline Interaction & SCsi5 & 1.000 & 0.863 & & & & & & \\
\hline & SCsi6 & 0.776 & 0.734 & 0.048 & 16.065 & $* * *$ & & & \\
\hline & SCst1 & 0.871 & 0.775 & 0.049 & 17.850 & $* * *$ & & & \\
\hline & SCst2 & 0.961 & 0.827 & 0.049 & 19.739 & $* * *$ & & & \\
\hline Social & SCst3 & 1.000 & 0.861 & & & & & & \\
\hline Integration & SCst4 & 0.935 & 0.732 & 0.057 & 16.430 & $* * *$ & 0.581 & 0.731 & 0.891 \\
\hline & SCst5 & 0.873 & 0.731 & 0.062 & 14.091 & $* * *$ & & & \\
\hline & SCst6 & 0.792 & 0.624 & 0.061 & 13.095 & $* * *$ & & & \\
\hline
\end{tabular}


Table 5. CFA on endogenous factors.

\begin{tabular}{|c|c|c|c|c|c|c|c|c|c|}
\hline Factors & Measures & Estimate & $\begin{array}{l}\text { Standardized } \\
\text { Estimate }\end{array}$ & S.E. & $\mathbf{T}$ & $\mathbf{P}$ & AVE & $\begin{array}{l}\text { Composite } \\
\text { Reliability }\end{array}$ & $\begin{array}{c}\text { Cronbach } \\
\alpha\end{array}$ \\
\hline \multirow{3}{*}{$\begin{array}{c}\text { Perceived } \\
\text { Intrusiveness }\end{array}$} & PI1 & 0.621 & 0.606 & 0.050 & 12.515 & $* * *$ & \multirow{3}{*}{0.647} & \multirow{3}{*}{0.717} & \multirow{3}{*}{0.833} \\
\hline & PI2 & 1.000 & 0.914 & & & & & & \\
\hline & PI3 & 0.950 & 0.861 & 0.050 & 18.866 & $* * *$ & & & \\
\hline Privacy & PC3 & 1.000 & 0.819 & & & & \multirow{3}{*}{0.537} & \multirow{2}{*}{0.555} & \multirow[b]{2}{*}{0.648} \\
\hline Concerns & PC4 & 0.751 & 0.635 & 0.116 & 6.453 & $* * *$ & & & \\
\hline Perceived & AL1 & 0.887 & 0.879 & 0.034 & 26.154 & $* * *$ & & \multirow{3}{*}{0.851} & \multirow{3}{*}{0.917} \\
\hline Advertising & AL2 & 1.000 & 0.954 & & & & \multirow[t]{2}{*}{0.792} & & \\
\hline \multirow[t]{3}{*}{ Value } & AL3 & 0.854 & 0.832 & 0.037 & 23.318 & $* * *$ & & & \\
\hline & AI1 & 0.736 & 0.734 & 0.044 & 16.587 & $* * *$ & \multirow{5}{*}{0.629} & \multirow{5}{*}{0.828} & \multirow{5}{*}{0.896} \\
\hline & $\mathrm{AI} 2$ & 0.869 & 0.824 & 0.043 & 20.079 & $* * *$ & & & \\
\hline \multirow[t]{4}{*}{ Irritation } & $\mathrm{AI} 3$ & 1.000 & 0.878 & & & & & & \\
\hline & AI4 & 0.877 & 0.802 & 0.045 & 19.322 & $* * *$ & & & \\
\hline & AI5 & 0.830 & 0.716 & 0.051 & 16.158 & $* * *$ & & & \\
\hline & AA1 & 1.000 & 0.780 & & & & \multirow{4}{*}{0.590} & \multirow{4}{*}{0.771} & \multirow{4}{*}{0.863} \\
\hline Advertising & AA2 & 0.963 & 0.777 & 0.064 & 14.972 & $* * *$ & & & \\
\hline \multirow[t]{2}{*}{ Avoidance } & AA3 & 0.844 & 0.712 & 0.063 & 13.495 & $* * *$ & & & \\
\hline & AA4 & 0.982 & 0.800 & 0.063 & 15.556 & $* * *$ & & & \\
\hline
\end{tabular}

Table 6. AVEs for discriminant validity.

\begin{tabular}{|c|c|c|c|c|c|c|c|c|c|c|c|c|c|c|c|c|}
\hline Factors & Mean & S.D. & UBts & UBsf & UBcf & Taps & TAct & IMif & IMen & SCsi & SCst & $\mathrm{AL}$ & PI & PC & AI & AA \\
\hline UBts & 4.959 & 1.176 & 0.803 & & & & & & & & & & & & & \\
\hline UBsf & 5.398 & 1.032 & $0.410^{* *}$ & 0.766 & & & & & & & & & & & & \\
\hline UBcf & 5.598 & 0.911 & $0.416^{\text {** }}$ & $0.641^{\text {** }}$ & 0.749 & & & & & & & & & & & \\
\hline TAps & 3.837 & 1.421 & 0.034 & $0.136 * *$ & 0.114 * & 0.829 & & & & & & & & & & \\
\hline TAct & 3.860 & 1.275 & $0.126^{*}$ & 0.193 ** & $0.166 * *$ & $0.546 * *$ & 0.776 & & & & & & & & & \\
\hline IMif & $\begin{array}{l}5.000 \\
4.037\end{array}$ & 1.223 & $\begin{array}{l}0.094 \\
0.09\end{array}$ & 0.213 ** & 0.190 ** & $0.502 * *$ & 0.566 ** & 0.773 & & & & & & & & \\
\hline IMen & 3.092 & 1.237 & -0.037 & 0.021 & $-112^{*}$ & 0.403 ** & $0.453 * *$ & 0.595 ** & 0.828 & & & & & & & \\
\hline SCsi & 3.727 & 1.226 & 0.047 & $0.147^{* *}$ & 0.033 & $0.286^{* *}$ & $0.410^{* *}$ & 0.512 ** & $0.606^{\text {** }}$ & 0.752 & & & & & & \\
\hline SCst & 3.456 & 1.118 & 0.102 * & $0.178^{\text {** }}$ & 0.078 & $0.412 * *$ & $0.500 * *$ & 0.526 ** & 0.613 ** & $0.666^{\text {*** }}$ & 0.762 & & & & & \\
\hline $\mathrm{AL}$ & 3.938 & 1.316 & 0.130 * & 0.127 * & 0.015 & 0.362 ** & 0.301 ** & 0.513 ** & $0.541^{* *}$ & $0.535 * *$ & $0.509 * *$ & 0.804 & & & & \\
\hline PI & 4.595 & 1.285 & 0.034 & 0.172 ** & 0.207 ** & -143 ** & 0.025 & -0.097 & -0.092 & -0.025 & -0.013 & $\begin{array}{l}-0.166 \text { ** } \\
\text { * }\end{array}$ & 0.733 & & & \\
\hline PC & 5.607 & 1.187 & $0.152^{* *}$ & $0.199 * *$ & $0.256 * *$ & -0.024 & -0.022 & 0.028 & $-113^{*}$ & -0.016 & $-166 * *$ & -0.049 & $0.296^{* *}$ & 0.890 & & \\
\hline AI & 4.868 & 1.114 & 0.076 & $0.116^{*}$ & $0.209 * *$ & $-296^{* *}$ & $-178^{* * *}$ & -345 ** & $-439 * *$ & $-327^{* * *}$ & $-310^{* *}$ & $-453 * *$ & $0.494^{* *}$ & $0.273^{* *}$ & 0.793 & \\
\hline AA & 5.474 & 1.105 & $0.145^{* *}$ & $0.187^{\text {** }}$ & $0.359 * *$ & $-199 * *$ & -170 ** & -247 ** & -436 ** & $-283 * *$ & -292 ** & -315 ** & 0.386 ** & 0.375 ** & $0.671^{* *}$ & 0.768 \\
\hline
\end{tabular}

Two-tailed: ${ }^{* *} p<0.01,{ }^{*} p<0.05$. Diagonal elements are square root of average variance extracted values.

\subsection{Common Method Variance and Response Bias}

To investigate if any serious bias resulted from the common method in our selfreported collected data, we subjected the data to Harman's one-factor test for confirmatory factor analysis. As suggested by Podsakoff et al. [78], a worse fit for the one-factor model indicates that the common-method variance is not a serious threat. In our study, the one-factor model for exogenous factors/endogenous factors yielded $\chi^{2}{ }_{(629)}=5350.827 / \chi^{2}(119)=1947.080$. Compared to the results of $\chi^{2}{ }_{(599)}=1211.236 / \chi_{(107)}^{2}=244.383$ in the measurement model for exogenous factors/endogenous factors, the fit was considerably worse, suggesting that common method bias was not a serious threat to exogenous or endogenous factors. Using the method described by Armstrong and Overton [79], we found no statistically significant differences in the research variables between the 30 early and the 30 late respondents (where the range of $p$ values was $0.194-0.89$ ), thereby confirming a lack of response bias [78,79].

\subsection{Hierarchical Regression Analysis with OLS}

Given the results of the measurement model assessment, we then used ordinal least square (OLS) regression to assess our research hypotheses, except for Hypothesis 5. To test our research model, we used SPSS 24 for the 374 valid responses. The results listed in Table 7 indicate the significant or non-significant $\beta$ coefficients in the research model, and the results validated the research hypotheses in Table 8 and Figure 1. 
Table 7. The results of hypotheses testing using hierarchical regression analysis with OLS.

\begin{tabular}{|c|c|c|c|c|c|c|}
\hline Variables & $\begin{array}{c}\text { Perceived } \\
\text { Intrusiveness }\end{array}$ & $\begin{array}{l}\text { Privacy } \\
\text { Concerns }\end{array}$ & $\begin{array}{l}\text { Privacy } \\
\text { Concerns }\end{array}$ & Irritation & $\begin{array}{l}\text { Advertising } \\
\text { Avoidance }\end{array}$ & $\begin{array}{l}\text { Advertising } \\
\text { Avoidance }\end{array}$ \\
\hline & Model 1 & Model 2 & Model 3 & Model 4 & Model 5 & Model 6 \\
\hline Intercept & 3.560 & 3.970 & 3.054 & 3.625 & 1.459 & 3.238 \\
\hline Ubiquity & $0.290 * * *$ & $0.380 * * *$ & $0.305^{* * *}$ & $0.130 * *$ & $0.209 * * *$ & $0.273^{* * *}$ \\
\hline Personalization & $-0.174 * * *$ & 0.012 & 0.057 & $-0.077^{*}$ & 0.032 & -0.005 \\
\hline Customization & $0.160 * *$ & -0.014 & -0.055 & 0.067 & -0.046 & -0.013 \\
\hline Informativeness & $-0.150 *$ & 0.090 & $0.129 *$ & $-0.108^{* *}$ & 0.019 & -0.033 \\
\hline Entertainment & -0.021 & -0.046 & -0.041 & $-0.205^{* * *}$ & $-0.151^{* * *}$ & $-0.251^{* * *}$ \\
\hline $\begin{array}{c}\text { Social } \\
\text { Interaction }\end{array}$ & 0.006 & $0.160 * *$ & $0.159 * *$ & $-0.104^{* *}$ & -0.014 & -0.065 \\
\hline $\begin{array}{c}\text { Social } \\
\text { Integration }\end{array}$ & 0.051 & $-0.351^{* * *}$ & $-0.364^{* * *}$ & -0.021 & -0.021 & -0.031 \\
\hline $\begin{array}{c}\text { Perceived } \\
\text { Intrusiveness }\end{array}$ & & & $0.257^{* * *}$ & $0.343^{* * *}$ & 0.052 & $0.220^{* * *}$ \\
\hline Privacy Concerns & & & & $0.096^{* *}$ & $0.148^{* * *}$ & $0.195^{* * *}$ \\
\hline Irritation & & & & & $0.491^{* * *}$ & \\
\hline$R^{2}$ & 0.079 & 0.128 & 0.199 & 0.440 & 0.541 & 0.404 \\
\hline \multirow[t]{2}{*}{ Adjusted $R^{2}$} & 0.062 & 0.111 & 0.182 & 0.426 & 0.529 & 0.398 \\
\hline & $\begin{array}{l}\text { Model 1: dep } \\
\text { 3: dependen } \\
\text { 4: dependen } \\
\text { variable = A } \\
* p<0.1 .\end{array}$ & $\begin{array}{l}\text { ent variable = } \\
\text { riable = Priva } \\
\text { iable = Irrita } \\
\text { tising Avoid }\end{array}$ & $\begin{array}{l}\text { ived Intrusi } \\
\text { ncerns inclu } \\
\text { lodel 5: dep } \\
\text { without Irrit }\end{array}$ & $\begin{array}{l}\text { s; Model 2: d } \\
\text { Perceived Ir } \\
\text { t variable = } \\
\text { as indepenc }\end{array}$ & $\begin{array}{l}\text { lent variable }= \\
\text { veness as inder } \\
\text { rtising Avoidar } \\
\text { ariable. Note: }\end{array}$ & $\begin{array}{l}\text { y Concerns; Mo } \\
\text { at variable; Mo } \\
\text { odel 6: depend } \\
<0.01 ;{ }^{* *} p<0\end{array}$ \\
\hline
\end{tabular}

Table 8. The results of hypotheses testing with hierarchical regression analysis.

\begin{tabular}{|c|c|c|c|c|c|c|c|}
\hline Hypotheses & Paths & $\begin{array}{c}\beta \\
\text { Coefficients }\end{array}$ & $\begin{array}{l}\text { Standard } \beta \\
\text { Coefficients }\end{array}$ & S.E. & $\mathbf{T}$ & $p$ & Results \\
\hline H1 & Irritation > Advertising Avoidance & 0.491 & 0.495 & 0.047 & 10.421 & $* * *$ & Accepted \\
\hline $\mathrm{H} 2$ & Perceived Intrusiveness $>$ Irritation & 0.343 & 0.395 & 0.037 & 9.258 & $* * *$ & Accepted \\
\hline H3 & $\begin{array}{c}\text { Perceived Intrusiveness }>\text { Privacy } \\
\text { Concerns }\end{array}$ & 0.257 & 0.278 & 0.045 & 5.705 & $* * *$ & Accepted \\
\hline $\mathrm{H} 4$ & Privacy Concerns > Irritation & 0.096 & 0.103 & 0.041 & 2.341 & 0.020 & Accepted \\
\hline H6a & Ubiquity $>$ Perceived Intrusiveness & 0.290 & 0.187 & 0.083 & 3.484 & 0.001 & Accepted \\
\hline $\mathrm{H} 6 \mathrm{~b}$ & Ubiquity > Privacy Concerns & 0.380 & 0.265 & 0.075 & 5.073 & $* * *$ & Accepted \\
\hline $\mathrm{H} 7 \mathrm{a}$ & $\begin{array}{c}\text { Personalization }>\text { Perceived } \\
\text { Intrusiveness }\end{array}$ & -0.174 & -0.192 & 0.057 & -3.035 & 0.003 & Accepted \\
\hline $\mathrm{H} 7 \mathrm{~b}$ & Personalization $>$ Privacy Concerns & 0.012 & 0.015 & 0.051 & 0.236 & 0.813 & Rejected \\
\hline $\mathrm{H} 7 \mathrm{c}$ & $\begin{array}{c}\text { Customization }>\text { Perceived } \\
\text { Intrusiveness }\end{array}$ & 0.160 & 0.159 & 0.068 & 2.338 & 0.020 & Accepted \\
\hline H7d & Customization $>$ Privacy Concerns & -0.061 & -0.069 & 0.091 & -0.663 & 0.507 & Rejected \\
\hline H8a & $\begin{array}{c}\text { Informativeness }>\text { Perceived } \\
\text { Intrusiveness }\end{array}$ & -0.150 & -0.143 & 0.077 & -1.956 & 0.051 & Accepted \\
\hline $\mathrm{H} 8 \mathrm{~b}$ & Informativeness $>$ Privacy Concerns & 0.090 & 0.093 & 0.069 & 1.310 & 0.191 & Rejected \\
\hline $\mathrm{H} 8 \mathrm{c}$ & $\begin{array}{c}\text { Entertainment }>\text { Perceived } \\
\text { Intrusiveness }\end{array}$ & -0.021 & -0.020 & 0.078 & -0.271 & 0.787 & Rejected \\
\hline H8d & Entertainment $>$ Privacy Concerns & -0.046 & -0.048 & 0.070 & -0.659 & 0.510 & Rejected \\
\hline H9a & $\begin{array}{c}\text { Social Interaction }>\text { Perceived } \\
\text { Intrusiveness }\end{array}$ & -0.006 & -0.005 & 0.076 & -0.074 & 0.941 & Rejected \\
\hline $\mathrm{H} 9 \mathrm{~b}$ & Social Interaction $>$ Privacy Concerns & 0.160 & 0.165 & 0.068 & 2.345 & 0.020 & Rejected \\
\hline $\mathrm{H} 9 \mathrm{c}$ & $\begin{array}{c}\text { Social Integration }>\text { Perceived } \\
\text { Intrusiveness }\end{array}$ & 0.051 & 0.044 & 0.087 & 0.586 & 0.558 & Rejected \\
\hline H9d & Social Integration $>$ Privacy Concerns & -0.351 & -0.331 & 0.078 & -4.496 & $* * *$ & Accepted \\
\hline
\end{tabular}




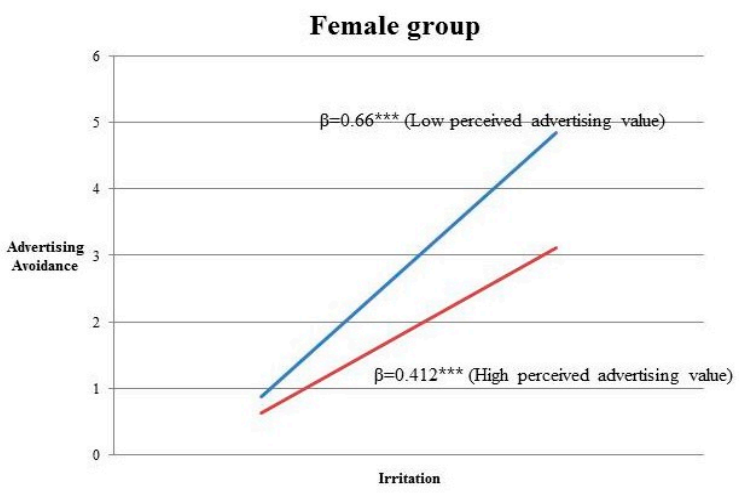

(a)

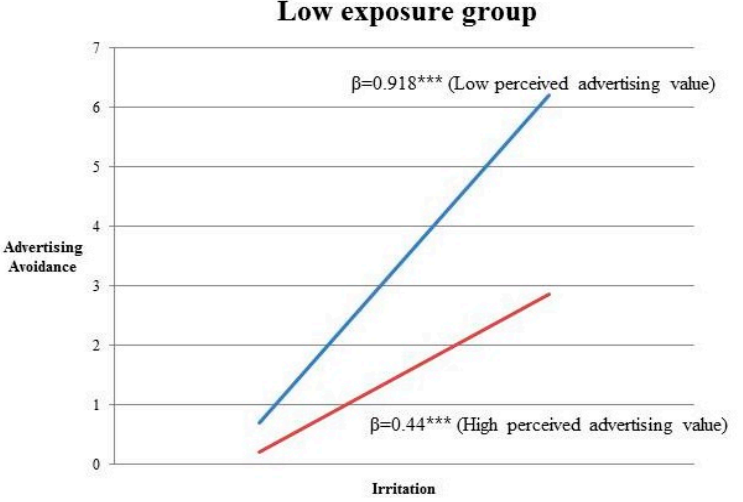

(b)

Figure 1. (a) Moderated mediation effect of perceived advertising value for women. (b) Moderated mediation effect of perceived advertising value in the low-exposure group.

Ubiquity played a negative role, and we empirically confirmed that it positively increased perceived intrusiveness $(\beta=0.290, p=0.001<0.010)$ and privacy concerns $(\beta=0.380, p=0.000<0.010)$. These results support H6 (both H6a and H6b). Personalization and customization empirically confirmed their distinct roles in advertising on mobile social media. For perceived intrusiveness, as anticipated, personalization showed a significant negative effect $(\beta=-0.174, p=0.003<0.010)$, and customization had a significant positive effect $(\beta=0.160, p=0.020<0.050)$ on it, which supports H7a and H7c, respectively. For privacy concerns, the distinct roles of personalization and customization were also apparent in the $\beta$ coefficients, where the coefficient of personalization was $\beta=0.012$ and the coefficient of customization was $\beta=-0.014$, as was consistent with our assumptions. However, both effects were statistically insignificant, thereby not supporting $\mathrm{H7b}$ and $\mathrm{H7d}$.

Second, informativeness decreased perceived intrusiveness $(\beta=-0.150, p=0.050)$, which supports H8a. The roles of entertainment in perceived intrusiveness and privacy concerns were both positive but not significant $(\beta=-0.021, p=0.787>0.050 ; \beta=-0.046$, $p=0.510>0.050)$, and the effect of informativeness on privacy concerns was positive but not significant $(\beta=0.090, p=0.191>0.050)$. Therefore, Hypotheses H8b, H8c, and H8d were not accepted.

Finally, we found ambiguous results. For perceived intrusiveness, the effects of social interaction $(\beta=-0.006, p=0.941>0.050)$ and social integration $(\beta=0.051, p=0.558>0.050)$ were both non-significant. However, for privacy concerns, social interaction $(\beta=0.160$, $p=0.020<0.100$ ) showed a positive and significant effect, whereas social integration $(\beta=-0.351, p=0.000<0.010)$ showed a negative and significant effect. Only the effect of social integration on privacy concerns was consistent with our assumption, which supported H9d; Hypotheses H9a, H9b, and H9c were rejected.

\subsection{Moderating Effects of Perceived Advertising Value}

We assessed the moderating effects in the research model that were outlined by Edwards and Lambert [63] that resulted from factors such as gender, exposure frequency, and media usage-time. We leveraged the classic bootstrapping-based analytic procedure developed by Hayes [68] to scrutinize the conditional indirect effect with 5000 repeated samples. The results based on gender, exposure frequency, and media usage-time are listed in Table 9, which suggested that there are significant moderating effects of perceived advertising value on the path ranging from irritation to advertising avoidance among the women (see Figure 1a) as well as in the group with a low-exposure frequency (see Figure 1b). The above results of the moderated mediation analysis partially support H5. There were some significant differences in beta coefficients caused by the perceived advertising value for women (low perceived advertising value group, $\beta=0.660$, $p=0.000<0.010$; high perceived advertising value group, $\beta=0.412, p=0.000<0.010$; 
$\triangle \beta=-0.248, p=0.000<0.010$ ) and the low-exposure group (low perceived advertising value group, $\beta=0.918, p=0.000<0.010$; high perceived advertising value group, $\beta=0.440$, $p=0.000<0.010 ; \triangle \beta=-0.478, p=0.000<0.010)$. H5a and H5b were supported. Finally, we show the results of our research model in Figure 2.

Table 9. Moderated mediating analysis of perceived advertising value.

\begin{tabular}{|c|c|c|c|c|c|}
\hline \multirow{3}{*}{$\begin{array}{c}\text { Moderator Variable: Perceived } \\
\text { Advertising Value }\end{array}$} & \multicolumn{5}{|c|}{ Perceived Intrusiveness $(X) \rightarrow$ Irritation $(M) \rightarrow$ Advertising Avoidance $(Y)$} \\
\hline & \multicolumn{2}{|c|}{ Stage } & \multicolumn{3}{|c|}{ Effect } \\
\hline & First & Second & Direct & Indirect & Total \\
\hline Male-195 & $P_{M X}$ & $P_{Y M}$ & $P_{Y X}$ & $\left(P_{Y M} \times P_{M X}\right)$ & $\begin{array}{c}\left(P_{Y X}+\right. \\
\left.P_{Y M} P_{M X}\right)\end{array}$ \\
\hline Low perceived advertising value ( -1 s.d.) & $0.455^{* * *}$ & $0.784^{* * *}$ & 0.029 & $0.357^{* * *}$ & $0.386^{* * *}$ \\
\hline High perceived advertising value ( +1 s.d.) & $0.307^{* * *}$ & $0.670^{* * *}$ & -0.005 & $0.206^{* * *}$ & $0.201 * *$ \\
\hline Differences between low and high & -0.148 & -0.114 & -0.034 & -0.151 & -0.185 \\
\hline Female-179 & $P_{M X}$ & $P_{Y M}$ & $P_{Y X}$ & $\left(P_{Y M} \times P_{M X}\right)$ & $\begin{array}{c}\left(P_{Y X}+\right. \\
\left.P_{Y M} P_{M X}\right)\end{array}$ \\
\hline Low perceived advertising value ( -1 s.d.) & $0.278^{* * *}$ & $0.660 * * *$ & 0.058 & $0.183^{* * *}$ & $0.242^{* * *}$ \\
\hline High perceived advertising value ( +1 s.d.) & $0.446^{* * *}$ & $0.412 * * *$ & $0.146^{*}$ & $0.184^{* * *}$ & $0.329^{* * *}$ \\
\hline \multicolumn{6}{|l|}{ H5a: Accepted } \\
\hline Exposure Frequency & First & Second & Direct & Indirect & Total \\
\hline Low exposure-164 & $P_{M X}$ & $P_{Y M}$ & $P_{Y X}$ & $\left(P_{Y M} \times P_{M X}\right)$ & $\begin{array}{c}\left(P_{Y X}+\right. \\
\left.P_{Y M} P_{M X}\right)\end{array}$ \\
\hline Low perceived advertising value ( -1 s.d.) & $0.381^{* * *}$ & $0.918^{* * *}$ & -0.025 & $0.350^{* * *}$ & $0.325^{* * *}$ \\
\hline High perceived advertising value ( +1 s.d.) & $0.437 * * *$ & $0.440 * * *$ & 0.059 & $0.192 * * *$ & $0.251^{* * *}$ \\
\hline Differences between low and high & 0.055 & $-0.478 * * *$ & 0.084 & $-0.158 * *$ & -0.073 \\
\hline High exposure-210 & $P_{M X}$ & $P_{Y M}$ & $P_{Y X}$ & $\left(P_{Y M} \times P_{M X}\right)$ & $\begin{array}{c}\left(P_{Y X}+\right. \\
\left.P_{Y M} P_{M X}\right)\end{array}$ \\
\hline Low perceived advertising value ( -1 s.d.) & $0.391 * * *$ & $0.505^{* * *}$ & 0.052 & $0.197^{* * *}$ & $0.249^{* * *}$ \\
\hline High perceived advertising value ( +1 s.d.) & $0.325^{* * *}$ & $0.623^{* * *}$ & 0.052 & $0.203^{* * *}$ & $0.255^{* * *}$ \\
\hline \multicolumn{6}{|l|}{ H5b: Accepted } \\
\hline Use Time & First & Second & Direct & Indirect & Total \\
\hline Low use time- 237 & $P_{M X}$ & $P_{Y M}$ & $P_{Y X}$ & $\left(P_{Y M} \times P_{M X}\right)$ & $\begin{array}{c}\left(P_{Y X}+\right. \\
\left.P_{Y M} P_{M X}\right)\end{array}$ \\
\hline Low perceived advertising value ( -1 s.d.) & $0.387^{* * *}$ & $0.678^{* * *}$ & 0.075 & $0.263^{* * *}$ & $0.338^{* * *}$ \\
\hline High perceived advertising value (+1 s.d.) & $0.345^{* * *}$ & $0.528 * * *$ & 0.025 & $0.182^{* * *}$ & $0.207 * *$ \\
\hline Differences between low and high & -0.042 & -0.150 & -0.050 & -0.081 & -0.131 \\
\hline High use time-137 & $P_{M X}$ & $P_{Y M}$ & $P_{Y X}$ & $\left(P_{Y M} \times P_{M X}\right)$ & $\begin{array}{c}\left(P_{Y X}+\right. \\
\left.P_{Y M} P_{M X}\right)\end{array}$ \\
\hline Low perceived advertising value ( -1 s.d.) & $0.361^{* * *}$ & $0.786^{* * *}$ & 0.010 & $0.283^{* * *}$ & $0.293^{* * *}$ \\
\hline High perceived advertising value ( +1 s.d.) & $0.421^{* * *}$ & $0.606^{* * *}$ & 0.126 & $0.255^{* * *}$ & $0.382 * * *$ \\
\hline $\begin{array}{l}\text { Differences between low and high } \\
\text { H5c: Rejected }\end{array}$ & \multicolumn{4}{|c|}{ H5c: Rejected } & 0.088 \\
\hline & First & Second & Direct & Indirect & Total \\
\hline Total Sample (374) & $P_{M X}$ & $P_{Y M}$ & $P_{Y X}$ & $\left(P_{Y M} \times P_{M X}\right)$ & $\begin{array}{c}\left(P_{Y X}+\right. \\
\left.P_{Y M} P_{M X}\right)\end{array}$ \\
\hline Low perceived advertising value ( -1 s.d.) & $0.38^{* * *}$ & $0.723 * * *$ & 0.049 & $0.275^{* * *}$ & $0.323^{* * *}$ \\
\hline High perceived advertising value (+1 s.d.) & $0.366^{* * *}$ & $0.557 * * *$ & 0.051 & $0.204^{* * *}$ & $0.255^{* * *}$ \\
\hline Differences between low and high & -0.013 & -0.166 & 0.003 & -0.070 & -0.068 \\
\hline
\end{tabular}




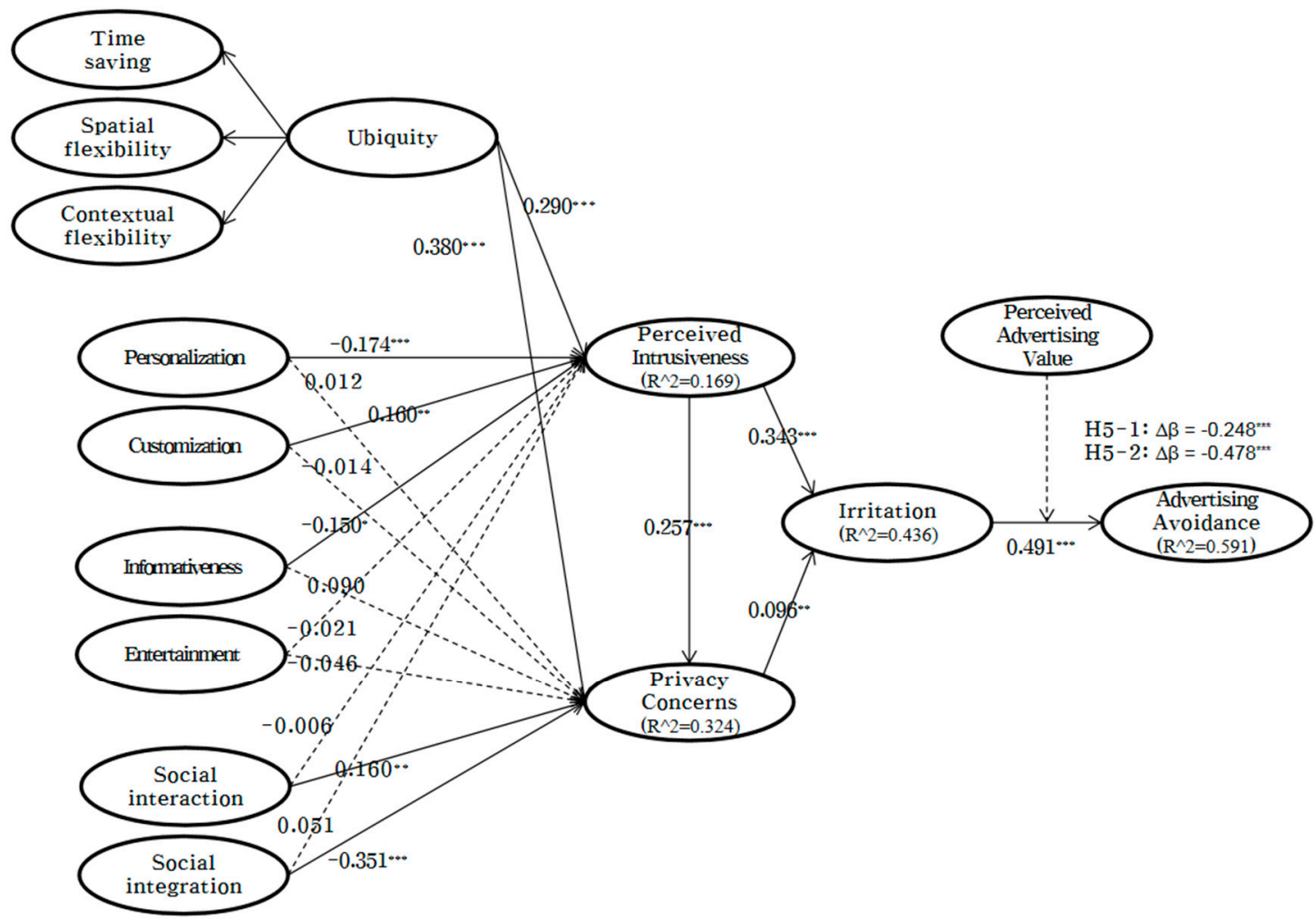

Figure 2. The results of the research model $\left({ }^{* *} p<0.01,{ }^{* *} p<0.05,{ }^{*} p<0.1\right)$.

\section{Conclusions}

In our study, we identified perceived intrusiveness, privacy concerns, and irritation as the determinants of advertising avoidance in mobile social media. The attributes of mobility consist of ubiquity and information tailoring. As expected, ubiquity plays a negative role in mobile social media, because it increases both perceived intrusiveness and privacy concerns. Customization and personalization played distinct roles in advertising. The distinct effects of personalization and customization on perceived intrusiveness are significantly confirmed by the results, showing that personalization decreased perceived intrusiveness and customization increase perceived intrusiveness. The effects of informativeness and entertainment are statistically insignificant in privacy concerns on mobile social media. Only informativeness decreased perceived intrusiveness. Social interaction and integration positively and negatively affect privacy concerns, respectively. However, the effects of social interaction and integration on perceived intrusiveness are both insignificant.

Both perceived intrusiveness and privacy concerns substantially aggravate advertising avoidance through irritation. When advertising is perceived as valuable, the feeling of interruption is effectively alleviated, thus resulting in less irritation [63]. We confirmed this view by our results for the women as well as for the group with less exposure, wherein the perceived advertising value effectively alleviated the effect of irritation on advertising avoidance. The results were also very similar to the results of studies insisting on the importance of the demographic variables in affecting advertising effectiveness [15,16,33-37]. We found strong mediation effects of irritation for perceived intrusiveness and privacy concerns related to advertising avoidance.

\section{Contributions, Discussions and Implications}

This study makes two main contributions to the understanding of advertising avoidance. First, for the uses of the general Internet [31] and social media [4,27], informativeness, entertainment, irritation, and advertising value were important antecedents of attitudes toward advertising. However, the important effects of perceived advertising value based on demographic characteristics have been underestimated. Demographic characteristics have 
been mentioned in other advertising studies: gender has been shown to play an important role in shaping advertising receptivity $[15,16,33,34]$. Advertising repetition significantly increases advertising effectiveness [35-37]. Consumer attitudes toward advertising are shaped by the amount of time spent on social media [1]. The results of our empirical analysis show significantly negative moderating effects of perceived advertising value on the trend related to irritation to avoid advertising. This suggests that advertising avoidance was alleviated among the women and the group with low exposure to advertising. These results confirmed the importance of considering certain characteristics (gender, advertising exposure frequency, and media usage time) in advertising studies. In addition, there are practical implications about marketing segmentation of advertising for marketing managers. In particular, to reduce advertising avoidance and increase advertising effectiveness, implementable programs should be developed for the group with less exposure to advertising, and especially for females in mobile social media.

Irritation, as a negative attitude, plays a strong mediating role in how perceived intrusiveness and privacy concerns affect advertising avoidance, which is an empirical application of the TRA in mobile social advertising. With the proliferation of social media, privacy has become a major issue of contemporary debate in the information and communication technology field [12,22,23]. Perceived intrusiveness as the determinant for advertising avoidance appears in various advertising media platforms (conventional mass media, the Internet, mobile platforms, and SNS). Unlike other studies, we combined perceived intrusiveness and privacy concerns to investigate advertising avoidance in mobile social media. We found that perceived intrusiveness affects privacy concerns and advertising avoidance as mediated by irritation, which is another contribution to research on advertising avoidance.

Second, given the features of mobility and socialization, our research findings have implications for theoretical research and practical management. We found a negative role of ubiquity for advertising, suggesting that the challenges to privacy that are associated with advertising greatly exceeded the benefits of mobile convenience. This finding provides some cautions that may be useful for advertisers. When conducting advertising campaigns in mobile social media, advertisers should pay attention to privacy and ad intrusions. Although the mobility of social media facilitates access to advertising information, given the sensitivity of information, privacy, and intrusiveness, advertising exposure based on gender differences would be a sound strategy.

The effects of personalization and customization on perceived intrusiveness contrast with each other, which represents a meaningful contribution to information tailored to advertising in the ICT field. Prior studies have suggested that personalization and customization affect user attitudes and behavior $[57,80,81]$. Personalization and customization had a close relationship to perceptions of privacy, which in turn differently affect attitudes toward news websites according to "usage power." "Power users" preferred system-initiated personalization with high privacy, but preferred user-initiated customization under low privacy [57]. In a study of location-based advertising experiments, user-tailored customization mediated by perceived intrusiveness was a more effective strategy than system-tailored personalization in inducing positive attitudes about location-based advertising [81]. We found significant differences in the effects of personalization and customization on advertising in mobile social media. More specifically, the coefficients of personalization are negative, whereas those of customization are positive. We statistically verified their direct effects, as interpreted by beta coefficients, on perceived intrusiveness and privacy concerns. Our results suggest some implications for the development of mobile social media in advertising. System-initiated personalization should be a primary concern in terms of privacy. However, in mobile social media, allowing for increasingly intensive personalization is a better way to alleviate advertising avoidance.

Informativeness alleviates perceived intrusiveness with statistical significance, but it increases privacy concerns with statistical insignificance. These findings suggest that having access to relevant and updated information in a timely fashion can decrease the 
perception of intrusiveness. Frequent access to entertainment content in specific time zones is highly valuable for customers, in that increasing access to "infotainment" minimizes advertising avoidance.

Contrary to our expectations, social interaction and social integration yielded ambiguous results in the mobile social context. We found clear effects of social interaction and social integration on privacy concerns. These results indicate that socialization is much more associated with privacy concerns [23]. In prior advertising-related studies, social gratification was shown to affect attitudes toward advertising [4,27,45]. However, with serious leaks of user information [12,22,23] from social media that threaten user privacy, a comprehensive discussion about the "social role" should be initiated. We found that social interaction increases privacy concerns, thereby confirming the results of [82]. Privacy concerns increase when users are more active in a social network. Social integration improves advertising effectiveness by reducing privacy concerns, which ensures the positive aspect of socialization. Thus, when promoting advertising via mobile social media, any interaction between consumers via advertising elicits some privacy concerns. However, forming a virtual social community to improve "social integration" is an effective approach to reducing privacy concerns, which subsequently minimizes advertising avoidance.

\section{Limitations and Future Study}

Although we found several interesting results by studying advertising avoidance in mobile social media, our study has limitations. First, the research subjects were mostly undergraduate students who were mostly in their twenties, who cannot represent the whole population of the advertising audience. Cultural variables also have to be included in advertising research [14]. A much wider and deeper investigation that considers the broader population as well as cultural differences can ensure the validity of our study's findings.

Second, researchers have proposed several determinants of advertising avoidance in diverse advertising contexts, such as perceived risk [27,34], ad clutter, and prior negative experience [60]. In our study, we investigated the relationships between perceived intrusiveness, privacy concerns, irritation, and advertising avoidance in terms of mobile social media. In future, combining experimental research and field studies to investigate advertising avoidance may increase the validity of the results and lead to interesting findings.

Finally, different types of SNS have different privacy controls. In addition, different SNS users have different privacy approaches. Future research on user privacy, power [57], and self-regulation [12] is needed to better tailor the effects of advertising via mobile social media.

Author Contributions: Conceptualization, X.W., I.K. and A.P; methodology, X.W.; Project administration, A.P.; Resources, A.P.; Writing—original draft, X.W.; Writing—review \& editing, I.K. All authors have read and agreed to the published version of the manuscript.

Funding: This research received no external funding.

Institutional Review Board Statement: Not applicable.

Informed Consent Statement: Informed consent was obtained from all subjects involved in the study.

Data Availability Statement: Not applicable.

Conflicts of Interest: The authors declare no conflict of interest.

\section{References}

1. Celebi, S.I. How do motives affect attitudes and behaviors toward internet advertising and Facebook advertising? Comput. Hum. Behav. 2015, 51, 312-324. [CrossRef]

2. Cheng, Y.; Liang, J.; Leung, L. Social network service use on mobile devices: An examination of gratifications, civic attitudes and civic engagement in China. New Media Soc. 2015, 17, 1096-1116. [CrossRef]

3. Duffett, R.G. The influence of Facebook advertising on cognitive attitudes amid Generation Y. Electron. Commer. Res. 2015, 15, 243-267. [CrossRef] 
4. Ho, K.K.; See-To, E.W. The impact of the uses and gratifications of tourist attraction fan page. Internet Res. 2018, 28, 587-603. [CrossRef]

5. Kim, Y.J.; Han, J. Why smartphone advertising attracts customers: A model of Web advertising, flow, and personalization. Comput Hum. Behav. 2014, 33, 256-269. [CrossRef]

6. Ko, H.; Cho, C.H.; Roberts, M.S. Internet uses and gratifications: A structural equation model of interactive advertising. J. Advert. 2005, 34, 57-70. [CrossRef]

7. Lee, J.; Ahn, J.H. Attention to Banner Ads and Their Effectiveness: An Eye-Tracking Approach. Int. J. Electron. Commer. 2012, 17, 119-137. [CrossRef]

8. Li, Y.M.; Lee, Y.L.; Lien, N.J. Online Social Advertising via Influential Endorsers. Int. J. Electron. Commer. 2012, 16, 119-154. [CrossRef]

9. Li, Y.; Lin, L.; Chiu, S. Enhancing Targeted Advertising with Social Context Endorsement. Int. J. Electron. Commer. 2014, 19, 99-128. [CrossRef]

10. Lo, S.K.; Hsieh, A.Y.; Chiu, Y.P. Keyword advertising is not what you think: Clicking and eye movement behaviors on keyword advertising. Electron. Commer. Res. Appl. 2014, 13, 221-228. [CrossRef]

11. Okazaki, S. Lessons learned from i-mode: What makes consumers click wireless banner ads? Comput. Hum. Behav. 2007, 23, 1692-1719. [CrossRef]

12. Ozcelik, A.B.; Varnali, K. Effectiveness of online behavioral targeting: A psychological perspective. Electron. Commer. Res. Appl. 2019, 33, 100819. [CrossRef]

13. Sanz-Blas, S.; Ruiz-Mafé, C.; Martí-Parreño, J. Message-driven factors influencing opening and forwarding of mobile advertising messages. Int. J. Mob. Commun. 2015, 13, 339-357. [CrossRef]

14. Sinkovics, R.R.; Pezderka, N.; Haghirian, P. Determinants of consumer perceptions toward mobile advertising-A comparison between Japan and Austria. J. Interact. Mark. 2012, 26, 21-32.

15. Taylor, D.G.; Lewin, J.E.; Strutton, D. Friends, fans, and followers: Do ads work on social networks? J. Advert. Res. 2011, 51, 258-275. [CrossRef]

16. Tran, G.A.; Strutton, D. What Factors Affect Consumer Acceptance Of In-Game Advertisements? J. Advert. Res. 2013, 53, 455-469. [CrossRef]

17. Tsang, M.M.; Shu-Chun, H.; Ting-Peng, L. Consumer Attitudes Toward Mobile Advertising: An Empirical Study. Int. J. Electron. Commer. 2004, 8, 65-78. [CrossRef]

18. Tseng, F.C.; Teng, C.I. Carefulness Matters: Consumer Responses to Short Message Service Advertising. Int. J. Electron. Commer. 2016, 20, 525-550. [CrossRef]

19. van Noort, G.; van Reijmersdal, E.A. Branded Apps: Explaining Effects of Brands' Mobile Phone Applications on Brand Responses. J. Interact. Mark. 2019, 45, 16-26. [CrossRef]

20. Varnali, K.; Yilmaz, C.; Toker, A. Predictors of attitudinal and behavioral outcomes in mobile advertising: A field experiment. Electron. Commer. Res. Appl. 2012, 11, 570-581. [CrossRef]

21. Rayport, J.F.; Jaworski, B.J. Introduction to E-Commerce; McGraw-Hill/Irwin marketspaceU: New York, NY, USA, 2002.

22. Gironda, J.T.; Korgaonkar, P.K. iSpy? Tailored versus invasive ads and consumers' perceptions of personalized advertising. Electron. Commer. Res. Appl. 2018, 29, 64-77. [CrossRef]

23. Toch, E.; Wang, Y.; Cranor, L.F. Personalization and privacy: A survey of privacy risks and remedies in personalization-based systems. User Modeling User-Adapt. Interact. 2012, 22, 203-220. [CrossRef]

24. Ha, Y.W.; Kim, J.; Libaque-Saenz, C.F.; Chang, Y.; Park, M.C. Use and gratifications of mobile SNSs: Facebook and KakaoTalk in Korea. Telemat. Inform. 2015, 32, 425-438. [CrossRef]

25. Castañeda, J.A.; Montoro, F.J. The effect of Internet general privacy concern on customer behavior. Electron. Commer. Res. 2007, 7 , 117-141. [CrossRef]

26. Smit, E.G.; Van Noort, G.; Voorveld, H.A. Understanding online behavioural advertising: User knowledge, privacy concern and online coping behaviour in Europe. Comput. Hum. Behav. 2014, 32, 15-22. [CrossRef]

27. Okazaki, S.; Molina, F.J.; Hirose, M. Mobile avoidance of advertising: Exploring the role of ubiquity. Electron. Mark. 2012, 22, 169-183. [CrossRef]

28. Smith, R.; Shao, J. Privacy and e-commerce: A consumer-centric perspective. Electron. Commer. Res. 2007, 7, 89-116. [CrossRef]

29. Wei, R.; Xiaoming, H.; Pan, J. Examining user behavioral response to SMS ads: Implications for the evolution of the mobile phone as a bona-fide medium. Telemat. Inform. 2010, 27, 32-41. [CrossRef]

30. Kim, J.; Lee, J.; Jo, S.; Jung, J.; Kang, J. Magazine reading experience and advertising engagement: A uses and gratifications perspective. J. Mass Commun. Q. 2015, 92, 179-198. [CrossRef]

31. Edwards, S.M.; Li, H.; Lee, J.H. Forced exposure and psychological reactance: Antecedents and consequences of the perceived intrusiveness of pop-up ads. J. Advert. 2002, 80, 83-95. [CrossRef]

32. Bae, S.; Lee, T. Gender differences in consumers' perception of online consumer reviews. Electron. Commer. Res. 2011, 11, 201-214. [CrossRef]

33. Doong, H.S.; Wang, H.C. Do males and females differ in how they perceive and elaborate on agent-based recommendations in Internet-based selling? Electron. Commer. Res. Appl. 2011, 10, 595-604. [CrossRef] 
34. Mukherjee, P.; Jansen, B.J. Performance analysis of keyword advertising campaign using gender-brand effect of search queries. Electron. Commer. Res. Appl. 2014, 13, 139-149. [CrossRef]

35. Agante, L.; Pascoal, A. How much is "too much" for a brand to use an advergame with children? J. Prod. Brand Manag. 2019, 28, 287-299. [CrossRef]

36. Burton, J.L.; Gollins, J.; McNeely, L.E.; Walls, D.M. Revisiting the Relationship between Ad Frequency and Purchase Intentions: How Affect and Cognition Mediate Outcomes At Different Levels of Advertising Frequency. J. Advert. Res. 2019, 59, 27-39. [CrossRef]

37. Catalán, S.; Martínez, E.; Wallace, E. Analysing mobile advergaming effectiveness: The role of flow, game repetition and brand familiarity. J. Prod. Brand Manag. 2019, 28, 502-514. [CrossRef]

38. Ducoffe, R.H. How consumers assess the value of advertising. J. Curr. Issues Res. Advert. 1995, 17, 1-18. [CrossRef]

39. Speck, P.S.; Elliott, M.T. Predictors of avoidance of advertising in print and broadcast media. J. Advert. 1997, 26, 61-76. [CrossRef]

40. Cho, C.H. Why do people avoid advertising on the internet? J. Advert. 2004, 33, 89-97. [CrossRef]

41. Kelly, L.; Kerr, G.; Drennan, J. Avoidance of advertising in social networking sites: The teenage perspective. J. Interact. Advert. 2010, 10, 16-27. [CrossRef]

42. Li, X.; Wang, C.; Zhang, Y. The dilemma of social commerce: Why customers avoid peer-generated advertisements in mobile social networks. Internet Res. 2020, 30, 1059-1080. [CrossRef]

43. Chen, Y.L.; Tang, K.; Wu, C.C.; Jheng, R.Y. Predicting the influence of users' posted information for eWOM advertising in social networks. Electron. Commer. Res. Appl. 2014, 13, 431-439. [CrossRef]

44. Zhang, K.Z.; Benyoucef, M.; Zhao, S.J. Building brand loyalty in social commerce: The case of brand microblogs. Electron. Commer. Res. Appl. 2016, 15, 14-25. [CrossRef]

45. Zywica, J.; Danowski, J. The faces of Facebookers: Investigating social increasement and social compensation hypotheses; predicting Facebook ${ }^{\mathrm{TM}}$ and offline popularity from sociability and self-esteem, and mapping the meanings of popularity with semantic networks. J. Comput. Mediat. Commun. 2008, 14, 1-34. [CrossRef]

46. Hartemo, M. Conversions on the rise-modernizing e-mail marketing practices by utilizing volunteered data. J. Res. Interact. Mark. 2021. [CrossRef]

47. Pagani, M.; Mirabello, A. The influence of personal and social-interactive engagement in social TV web sites. Int. J. Electron. Commer. 2011, 16, 41-68. [CrossRef]

48. Zhang, Y.; Li, X.; Hamari, J. How does mobility affect social media advertising effectiveness? A study in WeChat. Ind. Manag. Data Syst. 2020, 120, 2081-2101. [CrossRef]

49. Holiday, S.; Hayes, J.L.; Britt, B.C.; Lyu, Y. The cause effect: The impact of corporate social responsibility advertising on cause consumer engagement behavior after Brand affiliation ceases. Int. J. Advert. 2021, 40, 199-224. [CrossRef]

50. Sreejesh, S.; Paul, J.; Strong, C.; Pius, J. Consumer response towards social media advertising: Effect of media interactivity, its conditions and the underlying mechanism. Int. J. Inf. Manag. 2020, 54, 102155.

51. Dardis, F.; Schmierbach, M.; Sherrick, B.; Luckman, B. How game difficulty and ad framing influence memory of in-game advertisements. J. Consum. Mark. 2019, 36, 1-11. [CrossRef]

52. Richard, J.E.; Meuli, P.G. Exploring and modeling digital natives' intention to use permission-based location-aware mobile advertising. J. Mark. Manag. 2013, 29, 698-719. [CrossRef]

53. Malhotra, N.K.; Kim, S.S.; Agarwal, J. Internet users' information privacy concern (IUIPC): The construct, the scale, and a causal model. Inf. Syst. Res. 2004, 15, 336-355. [CrossRef]

54. Seyedghorban, Z.; Tahernejad, H.; Matanda, M.J. Reinquiry into avoidance of advertising on the internet: A conceptual replication and extension. J. Advert. 2016, 45, 120-129. [CrossRef]

55. Chi, H.H. Interactive digital advertising vs. virtual brand community: Exploratory study of user motivation and social media marketing responses in Taiwan. J. Interact. Advert. 2011, 12, 44-61. [CrossRef]

56. Balasubramanian, S.; Peterson, R.A.; Jarvenpaa, S.L. Exploring the implications of m-commerce for markets and marketing. J. Acad. Mark. Sci. 2002, 30, 348-361. [CrossRef]

57. Sundar, S.S.; Marathe, S.S. Personalization versus customization: The importance of agency, privacy, and power usage. Human Commun. Res. 2010, 36, 298-322. [CrossRef]

58. Rotzoll, K.B.; Haefner, J.E.; Hall, S.R. Advertising in Contemporary Society: Perspectives toward Understanding; University of Illinois Press: Champaign, IL, USA, 1996.

59. Ajzen, I. The theory of planned behavior. Organ. Behav. Hum. Decis. Process. 1991, 50, 179-211. [CrossRef]

60. Peters, S.; Leshner, G. Get in the game: The effects of game-product congruity and product placement proximity on game players' processing of brands embedded in advergames. J. Advert. 2013, 42, 113-130. [CrossRef]

61. Brehm, J.W.; Burke, W.W.; Lake, D.G.; Paine, J.V. A theory of psychological reactance. Organ. Chang. A Compr. Read. 2009, 377-390.

62. Gao, S.; Zang, Z. An empirical examination of users' adoption of mobile advertising in China. Inf. Dev. 2016, 32, 203-215. [CrossRef]

63. Edwards, J.R.; Lambert, L.S. Methods for integrating moderation and mediation: A general analytical framework using moderating path analysis. Psychol. Methods 2007, 12, 1. [CrossRef] [PubMed]

64. Galanxhi, H.; Nah, F.F.H. Privacy issues in the era of ubiquitous commerce. Electron. Mark. 2006, 16, 222-232. [CrossRef] 
65. Olsen, G.D.; Pracejus, J.W. Customized advertising: Allowing consumers to directly tailor messages leads to better outcomes for the brand. J. Bus. Res. 2020, 116, 245-257. [CrossRef]

66. Taylor, D.G.; Davis, D.F.; Jillapalli, R. Privacy concern and online personalization: The moderating effects of information control and compensation. Electron. Commer. Res. 2009, 9, 203-223. [CrossRef]

67. Dhar, S.; Varshney, U. Challenges and business models for mobile location-based services and advertising. Commun. ACM 2011, 54, 121-128. [CrossRef]

68. Hayes, A.F. Introduction to Mediation, Moderation, and Conditional Process Analysis: A Regression-Based Approach; Guilford Publications: New York, NY, USA, 2017.

69. Swanson, D.L. Political communication research and the uses and gratifications model a critique. Commun. Res. 1979, 6, 37-53. [CrossRef]

70. Ellison, N.B.; Steinfield, C.; Lampe, C. The benefits of Facebook "friends:" Social capital and college students' use of online social network sites. J. Comput. Mediat. Commun. 2007, 12, 1143-1168. [CrossRef]

71. Katz, E.; Blumler, J.G.; Gurevitch, M. Uses and gratifications research. Public Opin. Q. 1973, 37, 509-523. [CrossRef]

72. Okazaki, S. How do Japanese consumers perceive wireless ads? A multivariate analysis. Int. J. Advert. 2004, 23, 429-454. [CrossRef]

73. Quan-Haase, A.; Young, A.L. Uses and gratifications of social media: A comparison of Facebook and instant messaging. Bull. Sci. Technol. Soc. 2010, 30, 350-361. [CrossRef]

74. Chen, H.T.; Kim, Y. Problematic use of social network sites: The interactive relationship between gratifications sought and privacy concern. Cyberpsychol. Behav. Soc. Netw. 2013, 16, 806-812. [CrossRef]

75. Coleman, J.S. Social capital in the creation of human capital. Am. J. Sociol. 1988, 94, S95-S120. [CrossRef]

76. Cleff, E.B. Effective approaches to regulate mobile advertising: Moving towards a coordinated legal, self-regulatory and technical response. Comput. Law Secur. Rev. 2010, 26, 158-169. [CrossRef]

77. Fornell, C.; Larcker, D.F. Evaluating structural equation models with unobservable variables and measurement error. J. Mark. Res. 1981, 18, 39-50. [CrossRef]

78. Podsakoff, P.M.; MacKenzie, S.B.; Lee, J.Y.; Podsakoff, N.P. Common method biases in behavioral research: A critical review of the literature and recommended remedies. J. Appl. Psychol. 2003, 88, 879. [CrossRef]

79. Armstrong, J.S.; Overton, T.S. Estimating nonresponse bias in mail surveys. J. Mark. Res. 1977, 14, 396-402. [CrossRef]

80. Kalyanaraman, S.; Sundar, S.S. The psychological appeal of personalized content in web portals: Does customization affect attitudes and behavior? J. Commun. 2006, 56, 110-132. [CrossRef]

81. Lee, S.; Kim, K.J.; Sundar, S.S. Customization in location-based advertising: Effects of tailoring source, locational congruity, and product involvement on ad attitudes. Comput. Hum. Behav. 2015, 51, 336-343. [CrossRef]

82. Lewis, K.; Kaufman, J.; Christakis, N. The taste for privacy: An analysis of college student privacy settings in an online social network. J. Comput. Mediat. Commun. 2008, 14, 79-100. [CrossRef] 